\title{
Factors influencing the scientific production of university professors: a systematic review*
}

Factores que influyen en la producción científica de los docentes universitarios: una revisión sistemática

Fatores que influenciam a produção científica dos professores universitarios: uma revisão sistemática

DOI: https://doi.org/10.21803/pensam.v17121-1.276

Carlos Barros Bastidas

https://orcid.org/0000-0002-5364-7700

Osbaldo Turpo Gebera

https://orcid.org/0000-0003-2199-561X

\section{¿Cómo citar este artículo?}

Barros, C. \& Turpo, O. (2018). Factors influencing the scientific production of university professors: a systematic review. Pensamiento Americano, 11(22), 206-215.

\begin{abstract}
This article presents a bibliographical review of empirical studies of the factors influencing the scientific production of professors, with the objective of characterizing scientific production in the university and its determining factors. It was carried out through the analysis of articles that present the situation of institutions of higher education. To find these articles, search strings were used in various databases, including Scopus, Scielo, Taylor and Francis, and inclusive and exclusive terms were used to delimit the articles found. An analysis is provided of the factors influencing scientific production, based on type of institution training and professional development, as indicators of their essential characteristics.
\end{abstract}

Key words: Training, teaching, researchers.

\section{Resumen}

Este artículo presenta una revisión bibliográfica de los estudios empíricos de los factores que influyen en la producción científica de los profesores, con el objetivo de caracterizar la producción científica en la universidad y sus factores determinantes. Se llevó a cabo a través del análisis de artículos que presentan la situación de las instituciones de educación superior. Para encontrar estos artículos, se utilizaron banco de datos, incluidos Scopus, Scielo, Taylor y Francis, y se utilizaron términos inclusivos y exclusivos para delimitar los artículos encontrados. Se proporciona un análisis de los factores que influyen en la producción científica, según el tipo de capacitación de la institución y el desarrollo profesional, como indicadores de sus características esenciales.

Palabras clave: educación, educar, investigadores 


\section{Resumo}

Este artigo apresenta uma revisão bibliográfica de estudos empíricos dos fatores que influenciam a produção científica dos docentes, com o objetivo de caracterizar a produção científica na universidade e seus fatores determinantes. A pesquisa foi feita através de análises dos artigos que apresentam a situação das instituições de educação superior. Para encontrar estes artigos, foram usadas base de dados incluindo Scopus, Scielo, Taylor e Francis, termos inclusivos e exclusivos foram utilizados para delimitar os artigos encontrados. Foi providenciado uma análise dos fatores que influenciam a produção científica, baseado no tipo de treinamento da instituição e desenvolvimento profissional, como indicadores de suas características essenciais.

Palavras-chave: educação, lecionar, pesquisadores

\section{Perfil}

Doctorante en Educación de la Pontífice Univesidad Católica de Perú Docente de la Universidad Estatal de Guayaquil. Master en Gerencia Educativa. carlos_barros_b@me.com.

\section{Perfil}

Pontífice Univesidad católica de Perú Universidad Nacional de San Agustín de Arequipa oturpog@pucp.pe 


\section{Introducción}

Modern society needs the results of scientific study and the technologies generated in universities and centers that are destined for investigation and development. The socialization of these results in magazines, events and contests plays a distinctive role in the development of such outputs, allowing their generalization and valorization by the global scientific community. The research arm of the university is aware of the importance of these results and professors and students devote massive amounts of resources to scientific production, which to a high degree facilitates the accreditation of the processes of institutionalized university science.

In a preliminary review conducted on scientific activity and its productivity in universityies the university, a number of American and European authors stand out, namely Buela-Casal (2006); Codina-Canet, Gómez and Rodríguez (2013); Perozo, Arteaga and Fuenmayor (2008); Narvaez and Burgos (2011); Barner, Holosko and King (2015); Galbraith, Smart, Smith and Reed (2014); Zoellner, Hines, Keenan and Samson (2015); and Runyan, Finnegan, Gonzalez-Padron and Line (2016). These authors have systematized the institutional factors that either promote or delay scientific productivity. Such factors have been linked to labor demands, stimulation, and professorial improvement, and their research offers a holistic positioning of the review of their studies and analyses.

The articles of Perozo et al. (2008), Narvaez and Burgos (2011), Runyan, Finnegan, Gonzalez-Padron and Line (2016) and Palacios and Martin (2016), stand out because they examine how scientific publications are a requirement for university professors. In addition, the inclusion of master's and doctoral training programs on the North American continent, South American in studies represents an important indicator for the selection of articles, such as Gomes dos Reis and
Horvath (2014), Leech, Haug, Iceman-Sands and Moriarty (2014), Tenorio, do Amaral \& de Paiva (2014), Pirela de Faria \& de Alizo (2006) and Laurent and Runia (2016), it should also be taken into account, that regarding publications among different departments, empirical evidence from an European country suggests a "strong polarisation between top performers (very few) and weak performers (much more numerous)" (Miroiu, Păunescu \& Vîiu, 2015).

These articles show a relationship between the institutional formative pyramid and scientific production.

Although there are studies such as Don Houston (2015) that in his article Quality in postgraduate research "everything in the university is about how to pro- duce knowledge and capabilities: how to bring about learning" which presents not only the production of articles or products of research but the reproduction of knowledge.

Some of the studies present a more personalized perspective on scientific productivity, namely García-Cepero (2010), Pirela de Faria \& de Alizo, (2006) and Palacios and Martin , (2016), indicating that the researchers' cognition, as well as their motivations, interests and expectations, can determine or delay the variables being studied.

The theoretical analyses performed on the sources consulted, the frequent observations of the research process at the author's university, and accumulated experience in the field of study facilitate the approach taken in this article. This is an epistemic questioning of the determinants that condition or enhance institutionalized scientific production in higher education. For this reason, the objective of this article is the characterization of the university's scientific production and its determining factors.

The systematic review attempts to identify data

Pensamiento Americano Vol. 11 (22) · 2018 • Julio-Diciembre · Corporación Universitaria Americana • Barranquilla, Colombia • ISSN: $2027-2448$. 


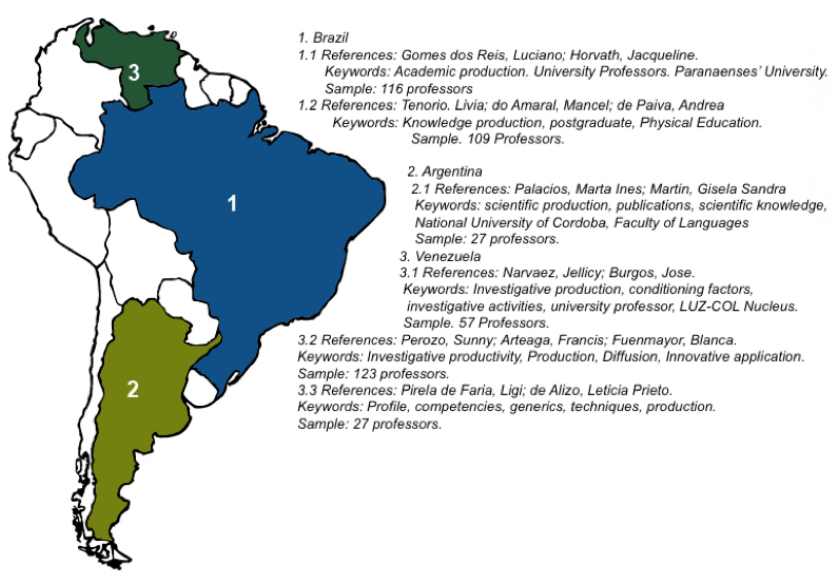

Graph 1: Articles related to the factors that influence scientific production in South America.

Source: Self-made.

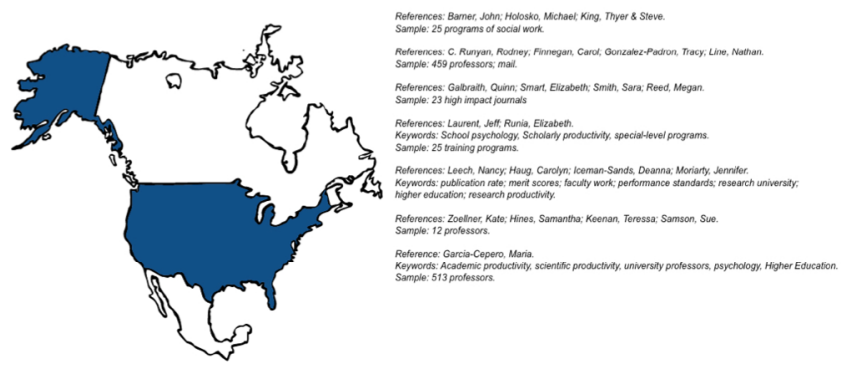

Graph 2: Articles related to the factors that influence scientific production in North America.

Source: Self-made.

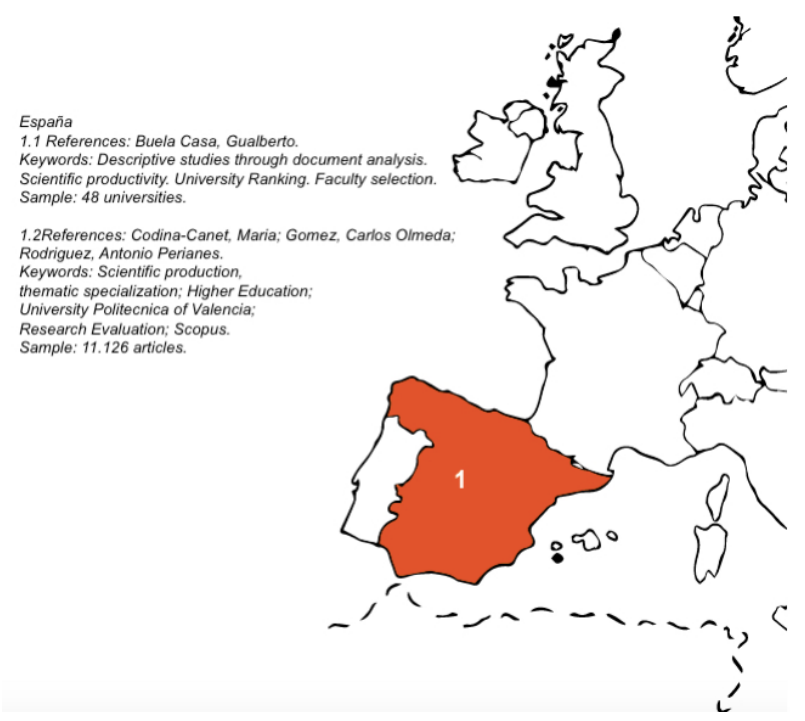

Graph 3: Articles related to the factors that influence scientific production in the country of Spanish in Europe.

Source: Self-made. for different Spanish American and North American countries (graphs 1, 2 and 3), highlighting the most relevant factors for scientific production from the results of various studies. The article systematizes the evidence found in empirical work on scientific production in universities.

The exclusion criteria facilitated the efficacy and precision of the search; among these, the following noteworthy: "academic production", "primary education", "initial education", "secondary education", "directors", "administrative training", "educational management", "teach", "teacher", "school" and "schoolteacher". The inclusion criteria in the systematic search were: "higher education", "productivity" "development professional growth", "professor advancement", "articles", "scientific production", "professional development", "research", "teacher research", "faculty", "training research", "faculty research", "faculty productivity" and "productivity development". With the aim of standardizing the subjects retrieved by our search terms. Universidad Nacional Autónoma de México(2008), the term scientific production is identified for the development of the systematic search.

To select and filter the information required, the following databases were consulted, using different search strings as required: WOS, Scielo, Scopus, Taylor and Francis Social Sciences, Eric and Redalyc. In Scielo, the following was applied (scientific production and year_cluster:("2013" or "2014" or "2010" or "2012" or "2015") and subject_ area:("health sciences") and type: ("research-article" or "review-article") and wok_subject_categories:("education \& educational research")). In Scopus, the following was used: (title-abs-key(faculty productivity) and (limit-to(exactsrctitle,"research in higher education" ) ) and ( limit-to(pubyear,2016) or limit-to(pubyear,2015) or limit-to(pubyear,2014) or limit-to(pubyear,2013) ) and (limit-to(doctype,"ar")) and (limit-to(subjarea,"soci")) and (limit-to(exactkeyword,"productivity") or limit-to(exactkeyword,"education") 
or limit-to(exactkeyword,"research" ) ) and ( limit-to(srctype,"j" ) ).

For the databases of Eric, Taylor and Francis, we used keywords referring to productivity, scholarship, educational research, faculty, research productivity and higher education.

For the organization of the data, the following information was recorded: the authors, years, theoretical contributions, population, methodology, results, and discussion. These indicators were fundamental for the bibliographical analysis, which identified factors- academic, institutional and personal - that revealed subdivisions within the data related to the research situation in universities.

In total, 57 articles were found in Scielo, of which 16 were pre-selected according to the inclusion criteria. In Eric, 14 articles were identified and analyzed to validate their contribution, leaving 4 pre-selected articles. In Scopus, 160 articles were collected, from which 23 were pre-selected. In Taylor and Francis, 314 articles were retrieved through keyword searches and 13 articles were pre-selected.

To arrive at concrete results in the present article, an argumentative logic composed of three theoretical elements that affect scientific production is adopted assumed. Based on the classification scheme derived from the authors previously mentioned, the factors chosen are the institutional factor, the training factor and the personal factor.

\section{Institutional Factor}

This factor, according to Perozo et al. (2008) describes the government's demand for research as a basic function in higher education; as is agreed as they include the development of professional processes and new domains of academia, bonding and university curricula. However, these same authors note the limited allocation of budget resources, go hand to hand of researchers dedicated to development.

The authors mentioned above describe a mode of development of scientific production that has little to do with social reality, but is presented to meet an established legal standard. One of causes lies in the need to ascend the faculty teaching ladder, which leads to the abandonment of projects that stray from research guidelines.

In a similar manner, Narvaez and Burgos (2011) professors at the University of Montana, point out that scientific production is presented individually and tends to meet the requirements of promotion up the university ladder rather than to conceive of research as a training program that enables the generation of scientific productivity. This situation ultimately generates scientific results for degree completion, but does not offer a systemic or holistic look at university research results.

In their article, Codina-Canet et al. (2013) suggest that universities should maintain their scientific-technical component by participating in projects and publishing articles and organize their scientific activities by participating in projects and conferences and research and technology transfer. To address this topic, they carried out a comparative study of the number of articles per institution for 3,000 European institutions in the SCImago network. This study yielded the result that $29 \%$ of the total production of the institutions of Valencia comes from the Polytechnic University of Valencia, which, at $12 \%$ of the annual production, is one of the universities with the greatest impact in the region. In addition, 99\% of production in the region in the 3rd and 4th quartile was in English, followed by $0.40 \%$ in Spanish. The Salesian Polytechnic University has a production of 14,185 articles in the SCImago ranking in various fields of study between 2007 and 2010; the contribution of social sciences to 
scientific productivity was 264 articles. This reveals that the valuation of institutions of higher education is linked to their percentage of disseminated scientific results.

Narvaez and Burgos analyze the scientific production of professors according to their training: 90\% had a master's degree and 40\% had a doctoral degree. It is thought that professors tend to show low levels of motivation to counsel and foster the development of postgraduates, even when their level of training meets institutional requirements. This indicator, in particular, reveals the dichotomous relationship between the professional level of the university Faculty cloister and the contribution to the formative pyramid of new scientists and, ultimately, new scientific production.

In their analysis, Runyan et al. (2016), show that one of the factors that leads to publication by non-tenured professors is the advantage they acquire when publishing in high-impact journals. At the same time, they indicate that doctoral and master's programs have no implications for a professor's publications. In this study, it is noted that the highest index of publications occurs between the process of recruitment or promotion to tenure. This indicator is taken from annual data published by the American Marketing Association, which publishes an essay about graduates that includes information on where they graduated from and who hired them, showing that the scientific productivity of institutions is relevant to the interests of those students and professors who are hoping to enter these universities.

\section{Training Factor}

The articles focusing on the institutional factor indicate that scientific production depends on factors such as the obligation to publish in order to enter university teaching or to remain in it as a requirement for the re-categorization of pro- fessors, or the personal interests of professional development.

The training factor is inferred from Palacios and Martin (2016), who identify the relationship between professors do not in postgraduate programs and their influence on the scientific production of a university. These authors offer comparative results that show a growth in scientific production with the incorporation of the first professors with research experience upon completion of their postgraduate studies. In this way, investment in the scientific training of professionals brings the university new approaches to the purposes and processes of science.

In the analysis of the training programs conducted by Gomes dos Reis and Horvath (2014), the impact of postgraduates on scientific production is presented. This study shows a production of 1.4 articles per professor over a 4-year period linked to the development of training programs. This reference facilitates the linking of university scientific production to postgraduate programs.

This analysis agrees with that of Tenorio et al. (2014), who focus their study of scientific production on training as a prime factor for the development of science. The authors conclude that the scientific production in Paraíba and Pernambucano during the period 2006-2011 was directly related to the master's and doctoral programs there, of which more than half received public funding as a contribution by public policy to the development of science, an indicator thus far not perceived in the private sector.

The authors Gomes dos Reis and Horvath (2014) reviewing articles from indexed journals during the period $2008-2012$, state that only $65 \%$ of postgraduates publish socialized results of their research during their degree program. This contrasts with the policy of improvement in education, giving the perception that the profile of researchers is not exploited after their training. 
An interesting analysis is found in the study by Laurent and Runia (2016), who selected 137 educational programs in the fields of psychology and humanities and identified 25 researchers with higher production and citation indexes in the databases according to bibliometric studies. This form of raking has relevance because it transcends the number of publications a researcher has produced, instead indicating the quality of the publications based on their utility and their contribution to other scientific results through citations and references.

The most prestigious universities worldwide have a factor of scientific productivity denoted by worldwide university rankings Shanghai Ranking Consultancy (2009), where the scale of the measurement of production is less dependent on the quantity of articles, books or presentations, but rather is based on their impact and on the measurement of the indexation bases that exist. Codina et al. (2013) highlight this aspect of university rankings in their analysis of the scientific production and thematic specialization of the Universities of Valencia in Scopus, where they employ deeper criteria than those mentioned above, such as the internationalization of science and the development of productivity from research projects; such factors are taken into account in the academic ranking of universities worldwide.

According to Buela-Casal (2006), using a sample of the 500 best universities in the world (ShanghaiRanking Consultancy, 2009), Spain has experienced a jump in its overall ranking of universities since 2004, reaching the 19th position for universities in 2010. This ranking was measured by scientific productivity, which is presented in a heterogeneous way, leading to the assumption that there are elite groups of universities with greater investment in research. Similarly, Tenorio et al. (2014) and Gomes dos Reis and Horvath (2014), note a strong impact in papers from doctoral programs and their relationship with scien- tific production, as this is an important factor for the publication of articles, papers and books. Buela-Casal (2006), in contrast to the situations found by Narvaez and Burgos (2011) and Perozo et al. (2008), indicate that in universities that facilitate entrance to professorship, their ternured professors are characterized by lower productivity.

The development of master's and doctoral programs shows a direct relationship to scientific production in higher education, thus the public sector contributes to this. Current scientific development requires enormous effort, not only in the quantity of socialized scientific results, but also in the quality of these results.

\section{Personal Factor}

Scientific production, according to Palacios and Martin (2016), can be viewed as a work of knowledge and of social recognition for the researcher that is produced from the perspective of a communicative act in the socialization of results that tend to be the personal self-realization of the scientist in particular and of the institution that represents them in general.

The study by Pirela de Faria and de Alizo (2006) focuses on professors' competencies stemming from professional development as a tool for confronting ideas, developing innovation, and contributing to solving social problems. Contribution distinguishes the eminently scientific role of the education professional and is not only a result of work, but is also a formative process and represents the development of a professor's personality. This is an aspect that particularly applies to researchers, but is generalizable to all professionals who graduate from the modern university.

Pirela de Faria and de Alizo (2006) conducted a study at the University of Zulia regarding some of the institution's professors' personal charac- 
teristics; among them, the following stood out: an average age of 42, and a majority of women dedicated to teaching. Furthermore, $22 \%$ of the cluster possessed a doctoral degree. In total, only 21 professors, 55.6\%, had published between 1 and 5 articles and $29 \%$ had published between 6 and 11. Given these data, we can conclude that the University of Zulia is characterized by a high level of scientific productivity. All this is due, according to the authors, to the levels of motivation and professional cooperation that can be observed among the professors and to the zest for improvement of the scientific process at the university.

The previous study presents an in-depth analysis, focusing not only on scientific production, but also on the academic factor of researchers, who must develop analytical thinking, motivation, conceptual thinking, knowledge and experience. This article, although focused on researcher's competency and training with regard to publishing, coincides with those of Tenorio et al. (2014), Gomes dos Reis \& Horvath, (2014), Buela-Casal (2006), Palacios and Martin, (2016) and Codina-Canet et al. (2013), who conclude that a professor's training is fundamental to scientific production, although they do not address the inside of the programs as Pirela de Faria \& de Alizo (2006) do.

In reviewing García-Cepero's academic productivity study of university professors García-Cepero (2010), individual production has different characteristics. This is important to know when identifying resources and necessities for scientific production, which are different from those required for individual research.

The purpose of the study by Leech et al. (2014), is to evaluate the scientific productivity of the faculty at the University of Western in the United States in order to measure institutional achievements based on the Carnegie ranking and to evaluate the changes that this produces in research environments. The study took as indicators the number of publications and the relationships with merit-related research for professors seeking tenure in educational field. The results indicate that, over time, the variables found to be important for the merits of professors changed and decreased in number, in accordance with the needs and aspirations of the researchers.

Barner's et al. (2015) article presents a study investigates cases in which universities' impact measurements, given by the $\mathrm{H}$ index, do not correspond to the samples that the universities present. It compares the scientific productivity of psychological and social sciences based on rankings with an analysis of public and private institutions, showing as a result that researchers' major focus is on the impact of their research, and ultimately on their professional achievements, rather than on the institutional impact of the research.

Similarly, Galbraith et al. (2014) studied bibliometrics in the United States, looking at 23 high-impact journals and noting the professor's tenure trajectory, the published author, and their work affiliation. This study concluded that the completed research is not recognized in its role of bolstering the institution, but rather in the individual professional development of the author. This reveals an individualized projection of science and its results, distanced from a more systemic and institutional approach.

According to a project maintained by the Institutional Board of Brigham Young University, which shows the identified authors in a ranking established by a study of a sample of 1,806 researchers, of which 994 are from the United States, it is inferred that most publish for reasons of academic status, while others researchers present factors similar to Narvaez and Burgos, (2011) Perozo et al. (2008) Codina-Canet et al. (2013), focusing on compliance with regulations. 
Zoellner et al. (2015) define the competencies for the systematic search of articles, identifying the methods applied to this work. They refer to the importance of repositories and the creation of strategies for the collection and storage of data based on a sample of 12 participants from the University of Montana. As a result, professors conduct their searches through the systematization and activities related to their subject and through the use of databases and collections in libraries; they are always motivated by established protocols, which leads to an improvement in the processes. Regarding primary and secondary searches, it is shown that the production of their articles is linked directly to online searches. From this, two essential considerations can be inferred: the particular motivations towards specific subjects as axes of development for scientific production and the tendency towards search and systematization, virtual or online.

The integral analysis of scientific production in its institutional, formative and personal factors facilitates the use of starting criteria to facilitate exchange and discussion with the community of sciences in general.

\section{Conclusions}

The factors analyzed in this article are the result of the identification of conditions that occur now of publishing from the different social perspectives of the sciences, as well as from the institutional, formative, and personal factors that characterize scientific production. The following aspects of analysis, incentive, and scientific exchange are offered.

Research is assumed to be a basic function of higher education as well as an integrative essence of the academic dimensions and an extension of the training. Research is closely connected with the society and the individual results of the professional who conducts it and their specific area of the sciences.
In the institutionalized view of scientific production, there is a direct relationship between the scientific degrees obtained and the results of research as an adjunct to university research progress.

Universities that promote or offer doctoral training enable the elevation of scientific production in their cloisters as well as in their doctorate students, as there are curricular requirements specific to the training process. The isolated scientific production of projects of postgraduate training becomes smaller in its conception and practical implementation.

Public policies linked to the development of science are seen as potentiators of scientific production, although this is more the case in the public sector than in the private sector; however, the context, training needs and political will regarding their integration determine whether social scientific results can be obtained that are immersed in other factors that can be developed in future investigations.

The logical necessity of valuing scientific production not by the quantity of articles but by their quality points to a requirement for relevance and contribution to science in the alma mater.

Scientific production is considered a primary result of the personal-professional self-realization of university teachers, and therefore contributes to the improvement of professional performance. This should ultimately be considered a result of professional work.

These activities and personal-professional competencies are essential to increasing the amount of scientific production, and universities must invest in them to achieve improvement in the indicators of study in this article. 


\section{Referencias}

Buela-Casal, G. (2006). Situación actual de la productividad científica de las universidades españolas. International Journal og Clinical and Health Psychology, 175-190.

Barner, J., Holosko, M. \& King, T. (2015). Research Productivity in Top-Ranked Schools in Psychology and Social Work: Does Having a Research Culture Matter? 5-18.

Galbraith, Q., Smart, E., Smith, S. \& Reed, M. (2014). Who Publishes in Top-Tier Library Science Journals? College \& Research Libraries, 724-735.

Runyan, C., Finnegan, R., Gonzalez-Padron, C. \& Line, N. (2016). What drives publishing productivity for pretenure marketing faculty: insights using the lens of resource advantage theory. Marketing Education Review. 23(2). 105-119.

Don Houston (2015) Quality in postgraduate research, Quality in Higher Education. 21(1). 1-6, DOI: 10.1080/13538322.2015.1049440

Codina-Canet, M., Gómez, C. O. \& Rodríguez, A. P. (2013). Análisis de la producción científica y de la especialización temática de la Universidad Politécnica de Valencia. Revista Española de Documentación Científica, 1-17.

García-Cepero, M. (2010). El estudio de productividad académica de profesores universitarios a través de análisis factorial confirmatorio: el caso de psicología en Estados Unidos de América. Universitas Phychologica. 9(1). 13-26.

Gomes dos Reis, L. \& Horvath, J. (2014). Uma análise sobre a produção acadêmica dos docentes das universidades estaduais paranaenses de 2008 a 2012. Revista GUAL, 22-42.

Laurent, J. \& Runia, E. (2016). Scholarly Productivity of School Psychology Faculty Members in Specialist-Level Programs. 48th Annual Convention of ther National Association of School. 1-35. New Orleans, LA: Psychologisst, New Orleans, LA.

Leech, N., Haug, C., Iceman-Sands, D. \& Moriarty, J. (2014). Change in classification level and the effects on research productivity and merit scores for faculty in school of education. Studies in Higher Education, 1030-1045.
Miroiu, A., Păunescu, M., \& Vîiu, G. A. (2015). Ranking Romanian academic departments in three fields of study using the g-index. Quality in Higher Education, 21(2), 189-212.

Narvaez, J. \& Burgos, J. (2011). La productividad investigativa del docente universitario. Revista Científica Electrónica de Ciencias Humanas/Scientific e-journal of Human Sciences, 116-140.

Palacios, M., \& Martin, G. (2016). La producción científica en la Facultad de Lenguas de la Universidad Nacional de Córdoba. Cinta de moebio, 214-230.

Perozo, S., Arteaga, F. \& Fuenmayor, B. (2008). La productividad investigativa de los docentes del instituto universitario de tecnología de Cabimas. Revista NEGOTIUM, 72-87.

Pirela de Faria, L. \& de Alizo, L. P. (2006). Perfil de competencias del docente en la función de investigador y su relación con la producción intelectual. opción, 22(50), 159-177.

ShanghaiRanking Consultancy. (23 de junio de 2009). Academic Ranking of World Universities. Obtenido de Academic Ranking: http://mww.shanghairanking. com/aboutus.html

Tenorio, L., do Amaral, M. \& de Paiva, A. (2014). Producción Científica en el área de educación física en Brasil: Análisis de la producción de los maestros en las instituciones de formación en los estados de Paraíba y Pernambuco. PraxisySaber, 141-150.

Universidad Nacional Autónoma de México. (2008). Vocabulario Controlado (tercera ed.). Mexico D.F.: ISSUE.

Zoellner, K., Hines, S., Keenan, T. \& Samson, S. (2015). Faculty Research and Publication Practices. 111-131.

2018, Vol. 11(22) 206-215. (T) The Author(s) 2018 Reprints and permission: www.americana.edu.co

https://www.coruniamericana.edu.co/publicaciones/ojs/index.php/pensamientoamericano/index

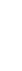

